\title{
ANTIOXIDANT AND PROTECTIVE EFFECT OF AROMATIC PLANTS BLEND INFUSION AGAINST OXIDATIVE STRESS OF STREPTOZOTOCINE AND CARBON TETRACHLORIDE IN RATS
}

\author{
Khaled F. El-massry*, Ahmed H. El-Ghorab, Manal M. Ramadan and Ahmed M. Gad \\ Flavour and Aroma Department - National Research Center, Dokki, Cairo, Egypt
}

\begin{abstract}
Aim of the work: The present study aimed to use some aromatic plants as ingredients to prepare a healthy drink with an acceptable flavour and taste and to evaluate its chemoprotective activity against oxidative stress induced by streptozotocin (STZ) and carbon tetrachloride $\left(\mathrm{CCl}_{4}\right)$ in rats. Materials and Methods: Infusion of guava leaves, linden, ginger, corn silk and chamomile was prepared, its volatiles were isolated and analyzed using GC and GC/MS, sensory evaluation as well as the total phenolic content were determined. The chemoprotective effectiveness of the blend infusion was tested by two separate biological experiments against the oxidative stress of STZ and $\mathrm{CCl}_{4}$. Serum glucose level was determine as well as liver function, kidney function, lipid profile, plasma hemoglobin, antioxidant enzymes and malonaldehyde (MDA) in some organs were investigated. Results: Thirty nine compounds were identified in the volatiles of blend infusion. The main components were 1,8cineol $(35.97 \%)$, cumene $(7.12 \%)$, guryunene $(5.25 \%), \beta$ - patchoulene $(4.55 \%)$, citronellol $(2.97 \%)$ and $\alpha$-zingiberene $(1.76 \%)$ and these compounds are related to the characteristic volatiles of the different aromatic plants that constitute the blend infusion. The blend infusion exhibits high score for all sensory attributes

The results showed that the supplementation with blend infusion to intoxicated rats either with STZ or $\mathrm{CCL}_{4}$ with blend infusion for four weeks significantly ameliorate most of the toxic effects and protecting pancreas, kidney and liver through improving their antioxidant status. In conclusion: The aromatic plants blend infusion was safe and effective in controlling hyperglycemic effects of STZ and improve lipid metabolism as well as its hepatoprotective activity against $\mathrm{CCl}_{4}$ by amelioration of the associated biochemical parameters.

Key words: Aromatic plants, GC-MS, Chemoprotection, Oxidative stress, Hyperglycemia, liver, kidney, Pancreas. *To whom correspondence; kfarouk@yahoo.com
\end{abstract}

\section{INTRODUCTION}

Herbs and spices have been used for thousands of years to enhance flavour, colour and aroma of food. In addition, they are also known for their preservative, antimicrobial, antioxidative (Shobana and Naidu, 2000) and various other medicinal values (Wood et al., 2001 radicals are generated continuously in the body due to metabolism and disease. In order to protect themselves against free radicals, organisms are endowed with endogenous).

Free- and exogenous antioxidant defenses; yet these defense systems are not sufficient in critical situations (oxidative stress, contamin-ation, UV exposure, etc.) where the production of free radicals significantly increases. It is generally assumed that the active dietary constituents contributing to these protective effects are the antioxidants e.g. vitamins, carotenoids, polyphenos and sterols (Yeum et al., 2003). The intake, in the human diet, of antioxidant compounds, or compounds that ameliorate or enhance the biological antiox-idant mechanisms, can prevent and in some cases help in treatment of some oxidative- related disorders and carcinogenic events (Havsteen, 2002). Natural plant products have been used empirically for this purpose 
since ancient times and tendency is emerging today for their increased used.

Presently, the use of herbal medicines for prevention and control of chronic liver diseases is in the focus of attention for the physicians, pharmaceutical manufacturers and patients; the reasons for such shift towards the use of herbals include the expensive cost of conventional drugs, adverse drug reactions, and their inefficacy. Approximately 800 plants worldwide have been documented to support antidiabetic effects, however a few comp-rehensive studies on traditional antidiabetic plants have been carried out (Alarcon-Aguilara et al., 1998 and Chhetri et al., 2005). Different aromatic plants with antioxidant, hypoglycemic, hypolipidimic, renal and hepatoprotective activities provide important sources for the development of new drugs in the treatment of many diseases (Cemek et al., 2008).

Herbal tea, which is generally a polyherbal formulation made up of different aromaic plants, is also considered as a source of antioxidants. These antioxidants found in herbal tea play an important role as a part of a healthy diet (Babenko and Shakhova, 2006). Herbal teas are reported to contain natural antioxidants such as vitamin $\mathrm{A}, \mathrm{B}_{6}$, $\mathrm{C}$, polyphenols, co-enzyme Q10, carotenoids, selenium, zinc and phytochemicals (Atoui et al., 2005). Many therapeutic properties such as neuroprotective, cardioprotective, chem.-oprotective, anticarcinogenic, hepatoprotc-tive, hypoglycemic and anti- inflammatory have been attributed to herbal preparations (Visioli et al., 2000; Campanella et al., 2003; Trouillasa et al., 2003; Luczaj and Skrzydlewska, 2005). Water extract (infusion) of different aromatic plants was found to be richer in polar phenols and therefore more effective in retarding lipid oxidation and in scavenging of free radicals than methanol, ethanol and acetone extracts of the same plant materials (Triantphyllou et al., 2001).

The present study aimed to use a miture of aromatic plants namely ginger, guava leaves, linden, corn silk and chamomile for the preparation of an acceptable drink and to evaluate its chemopreventive activity against oxidative stress induced by STZ and $\mathrm{CCL}_{4}$.

\section{MATERIAL AND METHODS}

\section{Chemicals and kits.}

Most of the kits used in this study were commercially purchased from Randox Laboratories (San Fransisco, CA, USA) and Biomerieux Laoratory of reagents and products (Mercy Letoile, France). All chemicals used were of analytical grade.

\section{Plant materials and Preparation of blend} infusion

Dry guava leaves, corn silk, linden flowers, chamomile and ginger root were purchased from local market and were identified by the department of Botany, Fac. Sci., Cairo university. The plants were separately grounded and blended at variable ratios (45\% guava leaves, $35 \%$ linden, $10 \%$ ginger, $5 \%$ corn silk and 5\% chamomile). One gram of the grounded plants blend was infused with $100 \mathrm{ml}$ freshly boiled water for $5 \mathrm{~min}$. followed by filtration. The infusion filtrate was subjected to further studies.

\section{Sensory evaluation}

The different sensory attributes (odour, colour, taste and appearance) of the blend infusion was estimated and scored by 15 assessors (Flavour and Aromatic Dept., NRC).The grading system was based on a total score of $100 \%$ of which $35 \%$ was awarded for odour, $35 \%$ for taste, $15 \%$ for colour and $15 \%$ for appearance (Liang et al., 2003).Isolation and analysis of the blend volatiles

Briefly, $100 \mathrm{~g}$ of powdered material was boiled in water $(1: 10 \mathrm{w} / \mathrm{v})$ for $4 \mathrm{~h}$. The water extract was filtered through Whatman No. 1 filter paper then extracted with $100 \mathrm{ml}$ of dichloromethane using a liquid- liquid continuous extractor for $6 \mathrm{~h}$. The volatile extract was dried over anhydrous sodium sulfate and the solvent was evaporated under vacuum at $40{ }^{\circ} \mathrm{C}$ followed by nitrogen stream until the volume was reduced to $0.5 \mathrm{ml}$. Volatile 
compounds in the blend aqueous extract obtained by three replicate experiments were identified by comparison with the Kovats gas chromatographic retention indices (Kovats, 1965) and by the mass spectral fragmentation pattern of each gas chromatographic (GC) component compared with those of authentic compounds and/or NIST/EPA/NIH Mass Spectral Library. An Agilent model 6890 gas chromatograph equipped with a $30 \mathrm{~m} \times$ $0.25 \mathrm{~mm}$ (inside diameter) (df $0.25 \mu \mathrm{m})$ bonded phase DB-5 fused silica) capillary column (Agilent, Folsom, CA) and a flame ionization detector (FID) was used to obtain the Kovats index, which was also compared with published data (Adams, 1995). The oven temperature was increased from 35 to $220{ }^{\circ} \mathrm{C}$ at a rate of $3{ }^{\circ} \mathrm{C} / \mathrm{min}$ and held for $40 \mathrm{~min}$. The linear helium carrier gas flow rate was $29 \mathrm{~cm} / \mathrm{s}$. The injector temperature was $200{ }^{\circ} \mathrm{C}$, and the detector temperature was $250{ }^{\circ} \mathrm{C}$. An Agilent model 6890 gas chromatograph interfaced with an Agilent 5791A mass selective detector (GC-MS) was used for mass spectral analysis of the GC components at a MS ionization voltage of $70 \mathrm{eV}$. A $30 \mathrm{~m} \times$ $0.25 \mathrm{~mm}$ (inside diameter) (df $0.25 \mu \mathrm{m}$ ) DB-5 bonded phase fused silica) capillary column (Agilent) was used for GC. The linear velocity of the helium carrier gas was $30 \mathrm{~cm} / \mathrm{s}$. The injector and the detector temperatures were $250{ }^{\circ} \mathrm{C}$. The oven temperature was increased from 35 to 220 ${ }^{\circ} \mathrm{C}$ at a rate of $3{ }^{\circ} \mathrm{C} / \mathrm{min}$ and held for 40 $\min$.

\section{Determination of total phenolic content}

Total phenolic content was determined in the blend infusion with Folin- Ciocalteu reagent as described by Kahkonen $\boldsymbol{e t}$ al . (1999) using gallic acid as the standard.

\section{Biological evaluation}

Animals and diets

Forty eight male Swiss albino rats with initial weights ranging from 150 to $170 \mathrm{~g}$ were provided from the breeding unit of the National Research Center (Cairo). The animals were maintained under laboratory condition for an acclimatization period for one week before performing the experiments. Throughout the experimental period the rats were fed on standard pellets (purchased from Cairo Company of Oil \& Soap, Egypt). The pellets contain 23\% protein, $6.5 \%$ fat, $4 \%$ fibers,

$8 \%$ ash, $2.5 \%$ added minerals and $56 \%$ carbohydrates. Rats were provided with food and water ad libitum.

\section{Hypoglycemic activity}

A total of 24 rats were divided into four groups (six rats/group) including the control group (Gr.I); the group received the prepared blend infusion ad libitum for four weeks instead of drinking water (Gr.II); the group i.p. injected with a single dose of STZ (52 $\mathrm{mg} / \mathrm{kg}$ b.w.)(Gr.III) and the group drink the blend infusion for two weeks followed by STZ injection and continued on the blend infusion drink for another two weeks (Gr.IV).

\section{Hepatoprotective activity}

Another 24 rats were divided into four groups (6rats/group) and treated as follows: the control group (Gr.I); Gr.II affored the blend infusion ad libitum for four weeks; Gr.III, i.p. injected with $\mathrm{CCL}_{4}(1.195 \mathrm{ml} / \mathrm{Kg}$ b.w.) three times a week for two weeks (Mac Sween et al. (1994) and Gr.IV, maintained on the blend infusion for four weeks and injected with $\mathrm{CCL}_{4}$ during the $3^{\text {rd }}$ and $4^{\text {th }}$ weeks (three times/week).

\section{Blood sampling}

At the end of experimental period, rats were lightly anesthetized with diethyl ether and blood samples were collected from sinus orbital puncture in heparinized test tubes then centrifuged for $15 \mathrm{~min}$ at 3000 r.p.m and the separated plasma was divided into small aliquots to avoid freezing and thawing. Aliquots were then stored at $20^{\circ} \mathrm{C}$ for biochemical measurements. The sediment contains red cells was washed several times with ice cold saline solution and the packed $\mathrm{RBCs}$ were stored at $-20^{\circ} \mathrm{C}$ for determination of antioxidant enzymes.

Tissue sampling and processing

After the collection of blood samples, all animals within different treatment groups were sacrified and samples of liver, kidney, spleen, heart and lung were removed and rinsed with cold saline, blotted dry and weighed then stored at $-20^{\circ} \mathrm{C}$ for malondialdehyde (MDA) determination. 


\section{Biochemical analyses}

The following biochemical anlyses were carried out: plasma glucose (Trinder, 1969), haemoglobin (International comm.ittee for standardization in hematology of the European society of hematology, 1965), Triglycerides (TG) Wahlefeld (1974), total cholesterol (TC) (Allain et al., 1974), HDL cholesterol (HDL-C) (Finley et al., 1978), urea (Tabacco et al., 1979) and creatinine (Bartel et al., 1972). The activities of glutathione reductase (GR) (Goldberg and Spooner, 1983), glutathione peroxidase (GPX) (Paglia and Valentine, 1967), superoxide dismutase (SOD) (Nishikimi et al., 1972), glucose-6-phosphate dehydrogenase (Glu-6-PDH) (Lohar and Wall, 1974), and plasma total antioxidant capacity (TAC) (Koracevic et al., 2001). Malondiadehyde (MDA) was determined spectrophotometrically according to Ohkawa et al. (1979). The activities of transaminases (ALT \& AST) (Bergmeyer et al., 1976), alkaline phosphatase (ALP) (Rosalki et al., 1993), $\gamma$ glutamyltransferase $(\gamma$-GT) (Szasz, 1976) and lactate dehydrogenase (LDH), (Anon, 1972). Total and direct bilirubin (Jendrassik and Grof, 1938), total proteins (Peters, 1968) and albumin (Doumas and Biggs, 1972).

\section{Statistical analysis}

All experimental data were expressed as mean \pm S.E. Significant differences among the groups were determined by one-way analysis of variance (ANOVA) using the SPSS statistical analysis program. Statistical significance was considered at $p$ $\leq 0.05$. All the statistical analysis was carried out according to Baily (1994).

\section{RESULTS AND DISCUSION}

\section{Volatile Constituents}

The chemical composition of the blend infusion volatiles was shown in Table1. The constituents were listed in order of their elution from the DB5 column. Thirty nine compounds were identified. The main constituents identified in the volatiles of blend herbal infusion were 1,8-cineol
(35.97\%), cumene $(7.12 \%)$, guryunene (5.25\%), $\beta$-patchoulene (4.55\%),

citronellol (2.97\%) and $\alpha$ - zingiberene $(1.76 \%)$ The reported components are related to different chemical classes namely, monoterpenes (M) (18.38\%), light oxygenated compounds (LOC) (54.62\%), sesquiterpenes (S) $(24.97 \%)$ and heavy oxygenated compounds (HOC) $(2.03 \%)$. It is obvious that these compounds are related to the characteristic volatiles of the different aromatic plants that constitute the blend infusion.

In this concern, Ramadan et al. (2008) reported the predominance of 1,8-cineol and other volatile components in the essential oil of Egyptian P. guajava leaves volatile oil. Da- Silva et al. (2003) and Chen et al. (2007) reported the presence of $\alpha$ - zin giberene as the major constituent in ginger oil. El-Ghorab et al. (2007) found that the volatile extract from Egyptian corn silk contained $\alpha$-terpineol, citronellol and $\alpha$-terpineol and other compounds.

Phenolic content and Sensory evaluation The content of phenolic compounds was calculated as milligram gallic acid equivalent per liter of herbal infusion. The total phenolic content of blend infusion was relatively high $(552 \pm 31 \mathrm{mg} \mathrm{GAE} / \mathrm{L})$. Also, the herbal infusion was subjected to a detailed sensory analysis concerning aroma, taste, colour and appearance and the total quality scores (TQS) of infusion was calculated. The blend infusion exhibits high scores for all sensory attributes (Table 2).

The high aroma quality of blend infusion is mainly ascribed to its aroma attributes and this is mainly due to the characteristic volatile constituents of blend. The presence of 1,8 cineol at high concentration (35.97\%) confirms the presence of fresh and minty note (Boelens and Boelens, 1997). Linalool $(0.65 \%)$ and $\alpha$-terpeneol $(1.26 \%)$ which are responsible for the floral note (Kumazawa and Masuda, 2002). Citronellol (2.97\%), possesses a fresh rosy odour and sabinene $(1.10 \%)$, which is one of the chemical compounds that contributes 
to the spiciness of black pepper (Arctander, 1969).

In the present study aromatic plants which are expected to possess promising antioxidant activities were selected and mixed at variable ratios in blend. Plant phenolic compounds have been considered to have multiple biological effects including antioxidant activity (Ito et al., 2005). The most important volatile constituents identified in the blend infusion (Table 1) were 1,8 cineol, cumene, guryunene, $\beta$-patchoulene, linalool, $\alpha$ terpineol, terpin-4-ol, $\alpha$-pinene and sabinen, most of them have antioxidant activity (Perry et al., 2003).

Hypoglycemic study

Glucose level and hemoglobin concentration

Supplementation with blend infusion to rats (Gr. II) did not affect plasma glucose level and blood hemoglobin concentration. In STZ treated rats (Gr. III) a significant ( $\mathrm{p}<$ 0.001 ) increase in fasting blood glucose level $(330 \%)$ was found compared to the control rats (Gr.I). On the other hand, diabetic animalsdrink the herbal infusion (Gr.IV), showed a significant decrease in blood glucose compared to the diabetic group (Gr.III)

(Table 3).Blood hemoglobin concentration was significantly decreased in diabetic rats (Gr.III). Obviously, supplementation of blend infusion to diabetic rats significantly improve $\mathrm{Hb}$ con-centration, compared to diabetic rats (Table 3 ).

Cemek et al., (2008), studied the antihyperglycemic and antioxidative activities of the ethanolic extract of aerial part of the Matricaria chamomilla L. in streptozotocin (STZ) induced diabetic rats and found that the extract significantly reduced postprandial hyperglycemia and oxidative stress as well as augmented the antioxidant system. This ascribed to protective effect on beta-cells in STZ-diabetic rats so diminished the hyperglycemia-related oxidative stress. Moreover, Akhani et al., (2004) studied the effect of the juice of ginger administration for 6 weeks on STZinduced diabetic rats. The authers reported that treatment with ginger juice produced a significant increase in insulin levels and a decrease in fasting glucose levels in diabetic rats as well as decrease in serum cholesterol, serum triglyceride and blood pressure. Furthermore, ginger aqueous extract could be of great value in managing the effects of diabetic complications in human subjects (Al-Amin et al., 2006 and Singh et al., 2008). and the extract of corn silk could be used as antidiabetic agent (Rau et al., 2006).

Some antidiabetic plants may exert their action by stimulating the function or number of $\beta-$ cells and thus increasing insulin release. In some other, the effect is due to decreased blood glucose synthesis due to the decrease of the activity of enzymes like glucose-6-phosphatase and fructose 1,6-bisphosphatase. Moreover, the activity may be due to slow the absorption of carbohydrate and the inhibition of glucose transport (Shalev, 1999; Eddokus et al., 2003; Villasenor and Lambardrid, 2006; Tomohiro et al., 2007).

The present study demonstrated that supple-mentation of hot water infusion of the five blended aromatic plants reduced plasma glucose level and improved hemoglobin level in STZ-induced diabetic rats and this could be explained by the higher antioxidant activity, the higher phenolic content and the hypoglycemic activity of the individual plant.

Lipid profile, kidney function and antioxidant biomarkers

The plasma triglyceride (TG), total cholesterol (TC), LDL- cholesterol (LDLC) and LDL/HDL ratio were significantly decreased in blend infusion supplemented rats (Gr.II). However, these levels were significantly elevated in the STZ- diabetic rats. Supp-lementation of the blend infusion to diabetic rats significantly reduced lipid profile levels compared to diabetic rats (Table 3 ). The treatment with blend infusion improved lipid profile by reducing the level of total cholesterol, triglycerides, and LDL-cholesterol and in the same time increased the level of HDLcholesterol.

The lipid lowering and antioxidant potential of ethanolic extract of ginger was 
evaluated in STZ-induced diabetes rats. Treatment with the extract lowered serum total cholesterol, triglycerides and increased the HDL-cholesterol levels compared with pathogenic diabetic rats. On the other hand, ginger extract lowered the liver and pancreas thiobarbituric acid reactive substances (TBARS) values as compared to pathogenic diabetic rats (Bhandari et al., 2005). The improvement of lipid profile produced by the treatment with blend fusion could be attributed to the plant phenolics that are found in blended plants.

Plasma urea and creatinine concentration were significantly higher in the diabetic rats than control rats. Supplementation of herbal infusion to diabetic rats significantly reduced these levels compared to diabetic group (Table 3). In this regards, Hisaki et al. (2005) proposed that the oxidative stress induced by STZ alters glomeruli function, resulting in the progression of diabetes and induces renal dysfunction. These authors reported that polyphenol antioxidant treatment attenuated the renal dysfunction, suggesting the beneficial effect of antioxidant treatment in diabetes.

Activities of various antioxidant enzymes (GR, GPx, SOD, Glu.6ph.DH) and the total antioxidant capacity (TAC) were significantly decreased in STZ- diabetic rats. On the other hand, concentration of malonaldehyde (MDA) in liver, spleen and kidney were significantly elevated compared to the non- diabetic groups.

Supplementation of blend infusion to diabetic rats significantly increased the activities of GR and GPx as well as plasma total antioxidant capacity level and reduced the MDA conce-ntrations, compared to group III. (Table 4).

The results of the present study demonstrated an elevation of MDA in STZinduced diabetic rats organs along with decrease in the antioxidant enzymes activity. Earlier reports documenting elevated lipid peroxide levels and diminished antioxidant status in diabetic subjects (Sato et al., 1979). As diabetes and its complications are associated with free radical mediated cellular injury (Oberley, 1988) herbal hypoglycemic agents were administered to diabetic rats to assess their anti-oxidant potential. The monoterpenoids 1,8-cineole, linalool, and $\alpha$-pinene present in the volatiles of blend fusion have been reported to be antioxidant, further to this any potential synergistic interactions could change the antioxidant profile of a whole plant extract (Perry et al., 2003).

Our results showed that the blend infusion not only have hypoglycemic activity but they also significantly reduce the MDA levels in diabetic rats. Moreover, following treatment, the activity of the antioxidant enzymes were also increased. The herbal hypoglycemic agents may also act by either directly scavenging the reactive oxygen metabolites, due to the presence of various antioxidant compounds (Gupta, et al., 2002), or by increasing the synthesis of anti-oxidant molecules.

\section{Hepatoprotective Study}

The results of hepatoprotective effects of blend infusion on $\mathrm{CCL}_{4}$ - intoxicated rats are shown in Table 5. The activities of liver enzymes; ALT, AST, ALP, $\gamma \mathrm{GT}, \mathrm{LDH}$ and total proteins, albumin, globulin and $\mathrm{A} / \mathrm{G}$ ratio as well as total, direct and indirect bilirubin levels in infusion supplemented rats (Gr.II) were comparable to those of control group (Gr.I). In $\mathrm{CCl}_{4}$ - intoxicated rats (group III), all the tested biochemical parameters were markedly disturbed. Supplementation of herbal infusion to intoxicated rats (Gr.IV) significantly improved liver function tests and these alterations appeared to be counteracted by infusion supplementation (Gr.IV). The present study showed, for the first time, that blend infusion of five aromatic plants possess hepatoprotective activity as evidenced by the significant inhibition in the elevated levels of serum enzyme activities as well as other biochemical parameters (Table 5).

It is well established that $\mathrm{CCl}_{4}$ hepatotoxicity by metabolic activation, therefore it selectively causes toxicity in liver cells maintaining semi-normal 
metabolic function. $\mathrm{CCl}_{4}$ is bio-transformed by the cytochrome $P 450$ system in the endoplasmic reticulum to produce trichloromethyl free radical $\left({ }^{*} \mathrm{CCl}_{3}\right)$. This free radical then combined with cellular lipids and proteins in the presence of oxygen to form a trichloromethyl peroxyl radical, which may attack lipids on the membrane of endoplasmic reticulum faster than trichloromethyl free radical. Thus, trichloromethylperoxyl free radical leads to elicit lipid peroxidation, the destruction of $\mathrm{Ca}^{2+}$ homeostasis, and finally, results in cell death (Britton and Bacon 1994).

Many compounds are known to be beneficial against carbon tetrachloridemediated liver injury and exert their protective action by toxin-mediated lipid peroxidation either via a decreased production of $\mathrm{CCl}_{4}$ derived free radicals or through the antioxidant activity of the protective agents themselves (Gupta and Misra 2006). The mechanism by which tested blend infusion exert its protective action against $\mathrm{CCl}_{4}$ induced alternations in the liver may be attributed to the antioxidant effect of the blend infusion; but this suggestion needs to be more exploited. El-Ghorab et al., (2007) reported that corn silk could be used to produce novel natural antioxidants as well as a flavouring agent in various food products. The hepatoprotective activity of corn silk extracts was studied on an acute hepatitis model. The extract decreased the activity of ALT, the levels of total bilirubin, the final malonaldehyde, diene conjugates as lipid peroxidation products, and absence of decline in the activity of glutathionedependent enzymes. The extracts exhibited antioxidant effects, which were proved by the reduction of the final and intermediate products of lipoperoxidization (Katikova et al., 2001).

Ajith et al. (2007) studied the hepatoprotective effect of aqueous ethanol extract of ginger against acetaminophen-induced acute toxicity and reported that aqueous ginger extract significantly protected against the hepatot-oxicity as evident from improvement in the activities of serum transaminases, alkaline phosphatase, liver SOD, CAT, glutathione peroxidase and

glutathione-S-transferase (GST), and reduced glutathione (GSH) levels. Matsuda et al. (2002) reported that ethanolic extract from the flowers of linden was found to have a hepatoprotective effect against D-galactosamine (D-GalN)/ lipopol-ysaccharide (LPS)-induced liver injury in mice. The authors isolated five flavonol glycol-sides as the hepatoprotective const-ituents of the tilia extract, that strongly inhibited serum GPT and GOT elevations in D-GalN/LPStreated mice. Manuele et al. (2008) reported that Tilia cordata flowers extract are rich in $\alpha$-pinene and $\beta$-pinene, that may thus constitute a potential source of monoterpenes with immunomodulatory acti-vity. Moreover, high performance liquid chromatography analysis indicated that the ethanol extract of tilia was constituted prin-cipally of tiliroside, quercetin, quercitrin, kaempherol, and their glycosides and these results supported the use of Tilia species intraditional medicine

(Herrera- Ruiz et al., 2008). Plant polyphenols are reported to exhibit antioxidant and antiinflammatory effects. Flavonoids of Germ-an chamomile are reported to exhibit the hepatoprotective effect (Chamomil represented 35\% of blend ingredients). Flavonoids normalized activities of key enzymes of sphingolipid turnover and ceramide contents in the damaged liver and liver cells, and stabilized the hepatocyte membranes (Babenko and Shakhova, 2006 and 2008). In conclusion, the significant antioxidant activity of blend infusion as well as the potential hypoglycemic and hepatoprot-ective effects of the blend infusion reported in the current study might be due to the scavenging of free radicals metabolites released from the toxicants such as $\mathrm{CCl}_{4}$ and $\mathrm{STZ}$ and could be attributed to the presence of phytochemicals mainly volatile compounds, considering that the guava leaves representing $45 \%$ of blend ingredients which are used for several ailments including diabete 
Khaled F. El-massry et al

Table 1. The Chemical composition of the volatile compounds of the aromatic plants blend infusion

\begin{tabular}{|c|c|c|c|}
\hline Compound Name & $\begin{array}{c}\text { Area } \\
\%\end{array}$ & $\mathbf{K} \mathbf{I}^{\mathbf{a}}$ & $\begin{array}{l}\text { Identification } \\
\text { Methods }{ }^{b}\end{array}$ \\
\hline \multicolumn{4}{|l|}{ Monoterpenes (M) } \\
\hline Santolina-triene & 1.05 & 908 & KI \&MS \\
\hline Cumene & 7.12 & 926 & KI \&MS \\
\hline$\alpha$-Pinene & 0.34 & 936 & KI \&MS\&St \\
\hline Verbenene & 1.09 & 976 & KI \&MS \\
\hline$\beta$-Pinene & 2.33 & 980 & KI \&MS \\
\hline Sabinene & 1.10 & 984 & KI \&MS \\
\hline Mesityllene & 2.78 & 994 & KI \&MS \\
\hline$P$-Cymene & 0.76 & 1026 & KI \&MS \\
\hline$\beta$-Ocimene $(z)$ & 1.43 & 1040 & KI \&MS \\
\hline$\gamma$-Terpinene & 0.38 & 1062 & KI \&MS \\
\hline \multicolumn{4}{|l|}{$\begin{array}{l}\text { Light Oxygenated } \\
\text { Compounds (LOC) }\end{array}$} \\
\hline Isovaleric acid & 0.12 & 831 & KI \&MS \\
\hline Hexenal (E-2-) & 0.21 & 854 & KI \&MS\&St \\
\hline Heptanone (3-methly-4-) & 1.93 & 929 & KI \&MS \\
\hline Heptanone(5-methly-3-) & 3.05 & 1943 & KI \&MS \\
\hline Isopropyl Tiglate & 0.7 & 973 & KI \&MS \\
\hline Hexenol Acetate(-E-3-) & 3.76 & 1004 & KI \&MS \\
\hline Cineole $(1,8)$ & 35.97 & 033 & KI \&MS\&St \\
\hline Linalool Oxide (cis) & 1.05 & 1074 & KI \&MS \\
\hline Iso-Terpinolene & 1.23 & 1086 & KI \&MS \\
\hline Linalool & 0.65 & 1098 & KI \&MS \\
\hline Terpin-4-ol & 1.24 & 1156 & KI \&MS\&St \\
\hline Phenyl-tert-butanol & 0.48 & 1156 & KI \&MS \\
\hline$\alpha$-Terpineol & 1.26 & 1198 & KI \&MS\&St \\
\hline Citronellol & 2.97 & 1234 & KI \&MS \\
\hline
\end{tabular}




\section{Sesquiterpenes $(\mathbf{S})$}

\begin{tabular}{|c|c|c|c|}
\hline Copaene $(\alpha-)$ & 0.77 & 1376 & KI \&MS \\
\hline$\beta$-patchoulene & 4.55 & 1380 & KI \&MS \\
\hline Cyperene & 0.84 & 1398 & KI \&MS \\
\hline Aromadendrene & 0.98 & 1436 & KI \&MS \\
\hline Thuyopsadiene & 3.48 & 1462 & KI \&MS \\
\hline Guryunene(y) & 5.25 & 1473 & KI \&MS \\
\hline Curcumene(ע) & 1.61 & 1480 & KI \&MS \\
\hline$\beta$-Selinene & 1.22 & 1489 & KI \&MS \\
\hline$\alpha$-Zingiberene & 1.76 & 1490 & KI \&MS \\
\hline$\beta$-Guaiene(Trans) & 0.94 & 1500 & KI \&MS \\
\hline $\begin{array}{c}\alpha \text {-Bisabolene } \\
\left(\mathrm{z}^{-}\right)\end{array}$ & 0.98 & 1504 & KI \&MS \\
\hline$\beta$-Bisabolene & 1.14 & 1509 & KI \&MS \\
\hline$\beta$-Cadinene & 1.45 & 1524 & KI \&MS \\
\hline \multicolumn{4}{|l|}{$\begin{array}{l}\text { Heavy Oxygenated } \\
\text { Compounds (HOC) }\end{array}$} \\
\hline Elemol & 1.58 & 1549 & KI \&MS \\
\hline Cubenol & 0.45 & 1644 & KI \&MS \\
\hline M & \multicolumn{3}{|c|}{18.38} \\
\hline LOC & \multicolumn{3}{|c|}{54.62} \\
\hline $\mathrm{S}$ & \multicolumn{3}{|c|}{24.97} \\
\hline $\mathrm{HOC}$ & \multicolumn{3}{|c|}{02.03} \\
\hline
\end{tabular}

KI: Kovat index; MS: Mass spectra, ST: available standards. 
Table 2. The sensory quality scores of the aromatic plants blend infusion*

\begin{tabular}{ccc}
\hline Quality & Maximum Score & Score \\
\hline Aroma & 35 & $32.1 \pm 3.5$ \\
Taste & 35 & $30.3 \pm 2.4$ \\
Colour & 15 & $12.4 \pm 1.7$ \\
Appearance & 15 & $13.6 \pm 1.2$ \\
Total quality score & 100 & $88.4 \pm 7.9$ \\
\hline
\end{tabular}

*The total phenolic content was 552 $\pm 31 \mathrm{mg} \mathrm{GAE} / \mathrm{L}$

Table 3. Hypoglycemic, hypolipidemic and renal protective activity of the aromatic plants blend infusion in STZ- treated rats

\begin{tabular}{|c|c|c|c|c|c|c|c|c|c|}
\hline & $\begin{array}{c}\text { TG } \\
(\mathbf{m g} / \mathbf{d l})\end{array}$ & $\begin{array}{c}\text { TC } \\
(\mathbf{m g} / \mathbf{d l})\end{array}$ & $\begin{array}{c}\text { LDL } \\
(\mathbf{m g} / \mathbf{d l})\end{array}$ & $\begin{array}{c}\text { HDL } \\
\text { (mg/dl) }\end{array}$ & LDL/HDL & $\begin{array}{c}\text { Urea } \\
\text { (mg/dl) }\end{array}$ & $\begin{array}{c}\text { Creatinine } \\
\text { (mg/dl) }\end{array}$ & $\begin{array}{c}\text { Hemoglobin } \\
\text { (mg/dl) }\end{array}$ & $\begin{array}{l}\begin{array}{c}\text { Glucose } \\
(\mathrm{mg} / \mathrm{dl})\end{array}\end{array}$ \\
\hline $\begin{array}{l}\text { Normal control } \\
\text { (Group I) }\end{array}$ & $201 \pm 11^{\mathrm{a}}$ & $192 \pm 8.9^{\mathrm{a}}$ & $101 \pm 8.5^{\mathrm{a}}$ & $86 \pm 5.9^{\mathrm{a}}$ & $1.17 \pm 0.06^{\mathrm{a}}$ & $51.2 \pm 4.1^{\mathrm{a}}$ & $0.51 \pm 0.017^{\mathrm{a}}$ & $13.61 \pm 0.61^{\mathrm{a}}$ & $92.5 \pm 5.3^{\mathrm{a}}$ \\
\hline $\begin{array}{l}\text { Blend } \\
\text { supplemented } \\
\text { (Group II) }\end{array}$ & $178 \pm 9^{\mathrm{b}}$ & $170 \pm 6.2^{\mathrm{b}}$ & $85 \pm 4.5^{b}$ & $83 \pm 6.5^{\mathrm{a}}$ & $1.02 \pm 0.03^{\mathrm{b}}$ & $50.0 \pm 2.1^{\mathrm{a}}$ & $0.49 \pm 0.19^{\mathrm{a}}$ & $13.11 \pm 0.72^{\mathrm{ab}}$ & $90 \pm 4.8^{\mathrm{a}}$ \\
\hline $\begin{array}{l}\text { STZ- diabetic } \\
\text { (Group III) }\end{array}$ & $297 \pm 13^{c}$ & $251 \pm 14^{c}$ & $147 \pm 11.9^{c}$ & $100 \pm 9.2^{\mathrm{b}}$ & $1.47 \pm 0.04^{\mathrm{c}}$ & $143 \pm 9.9^{b}$ & $3.82 \pm 0.09^{b}$ & $11 . .64 \pm 0.51^{\mathrm{c}}$ & $410 \pm 31^{\mathrm{b}}$ \\
\hline $\begin{array}{l}\text { Protected group } \\
\text { (Group IV) }\end{array}$ & $211 \pm 12^{\mathrm{a}}$ & $203 \pm 11^{\mathrm{a}}$ & $99 \pm 4.9^{\mathrm{a}}$ & $101 \pm 8.2^{\mathrm{b}}$ & $0.98 \pm 0.01^{\mathrm{b}}$ & $88.3 \pm 6.4^{c}$ & $1.98 \pm 0.07^{\mathrm{c}}$ & $12.97 \pm 0.55^{\mathrm{b}}$ & $218 \pm 14^{\mathrm{c}}$ \\
\hline
\end{tabular}


ANTIOXIDANT AND PROTECTIVE EFFECT OF....

Table 4. The antioxidant activity of the aromatic plants blend infusion in STZtreated rats

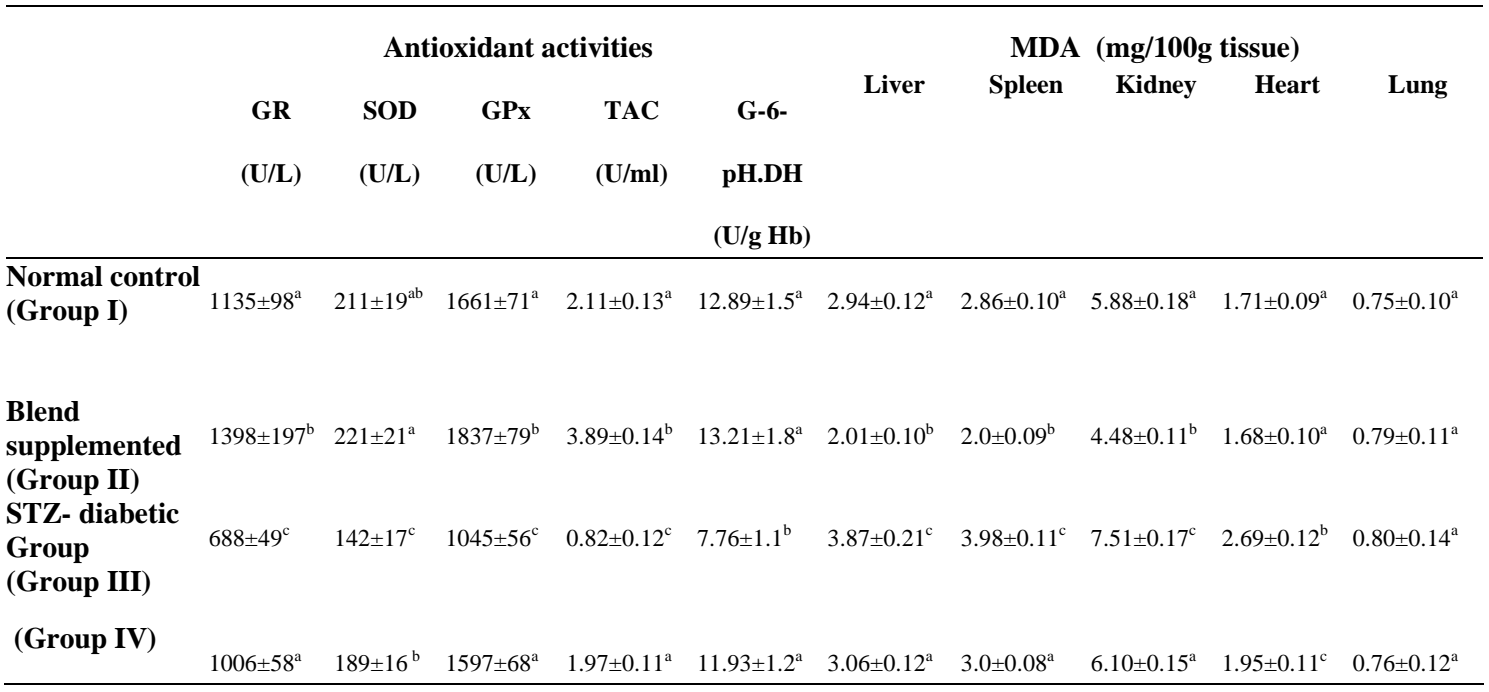

GR: Glutathione reductase; SOD: Superoxid Dismutase; GPx: Glutathion peroxidase (U/L); TAC Total antioxidant capacity (U/ml) and G-6-Ph.DH: Glucose-6- ph.dehydrogenase (U/g Hb); MDA; Malondialdehyde . a,b and c: In each column means with different letters are significantly different $(\mathrm{P} \leq 0.05)$.

Table 5. The hepatoprotective activity of the aromatic plants blend infusion in CCL4treated rats

\begin{tabular}{|c|c|c|c|c|c|c|c|c|c|c|c|c|}
\hline & \multirow[b]{2}{*}{$\gamma$-GT } & \multicolumn{4}{|c|}{$\begin{array}{c}\text { Plasma liver enzymes activities } \\
(\mathbf{U} / \mathrm{L})\end{array}$} & \multicolumn{4}{|c|}{ Plasma proteins levels (mg/dl) } & \multicolumn{3}{|c|}{$\begin{array}{l}\text { Bilirubin } \\
\text { (mg/dl) }\end{array}$} \\
\hline & & LDH & ALT & AST & $\mathbf{A L P}$ & T.P & ALB & GLB & $\mathbf{A} / \mathbf{G}$ & Total & Direct & Indirect \\
\hline $\begin{array}{c}\text { Normal } \\
\text { control } \\
\text { (Group I) }\end{array}$ & $26.8 \pm 1.2^{\mathrm{a}}$ & $686 \pm 30^{\mathrm{a}}$ & $48.2 \pm 3.8^{\mathrm{a}}$ & $120 \pm 10^{\mathrm{a}}$ & $360 \pm 18^{\mathrm{a}}$ & $9.3 \pm 0.77^{\mathrm{a}}$ & $5.2 \pm 0.61^{\mathrm{a}}$ & $4.1 \pm 0.31^{\mathrm{a}}$ & $1.26 \pm 0.11^{\mathrm{a}}$ & $0.42 \pm 0.021^{\mathrm{a}}$ & $0.19 \pm 0.009^{\mathrm{a}}$ & $0.23 \pm 0.008^{\mathrm{a}}$ \\
\hline $\begin{array}{c}\text { Blend } \\
\text { supplemented } \\
\text { (Group II) }\end{array}$ & $26.13 \pm 1.3^{\mathrm{a}}$ & $671 \pm 48^{\mathrm{a}}$ & $49.1 \pm 2.6^{\mathrm{a}}$ & $123 \pm 7.8^{\mathrm{a}}$ & $371 \pm 21^{\mathrm{ab}}$ & $9.1 \pm 0.61^{\mathrm{a}}$ & $5.0 \pm 0.47^{\mathrm{a}}$ & $4.1 \pm 0.28^{\mathrm{a}}$ & $1.21 \pm 0.09^{\mathrm{a}}$ & $0.4 \pm 0.016^{\mathrm{a}}$ & $0.19 \pm 0.019^{\mathrm{a}}$ & $0.21 \pm 0.020^{\mathrm{a}}$ \\
\hline $\begin{array}{c}\mathrm{CCl}_{4-} \\
\text { intoxicated } \\
\text { (Group III) }\end{array}$ & $31.14 \pm 1.5^{\mathrm{b}}$ & $1572 \pm 82^{b}$ & $206 \pm 11^{b}$ & $254 \pm 18^{b}$ & $817 \pm 61^{\mathrm{c}}$ & $5.7 \pm 0.31^{b}$ & $3.1 \pm 0.22^{b}$ & $2.6 \pm 0.16^{\mathrm{b}}$ & $1.19 \pm 0.11^{b}$ & $1.11 \pm 0.08^{\mathrm{b}}$ & $0.36 \pm 0.027^{b}$ & $0.75 \pm 0.054^{\mathrm{b}}$ \\
\hline $\begin{array}{c}\text { Protected } \\
\text { group } \\
\text { (Group IV1) }\end{array}$ & $27.11 \pm 1.4^{\mathrm{a}}$ & $713 \pm 54^{\mathrm{a}}$ & $52 \pm .3 .8^{\mathrm{a}}$ & $129 \pm 6.8^{\mathrm{a}}$ & $393 \pm 29^{b}$ & $8.9 \pm 0.65^{\mathrm{a}}$ & $5.0 \pm 0.41^{\mathrm{a}}$ & $3.9 \pm 0.24^{\mathrm{a}}$ & $1.28 \pm 0.13^{\mathrm{a}}$ & $0.42 \pm 0.03^{\mathrm{a}}$ & $0.2 \pm 0.017^{\mathrm{a}}$ & $0.23 \pm 0.016^{\mathrm{a}}$ \\
\hline
\end{tabular}

$\gamma$-GT: $\gamma$-glutamyltransferase ; ALT and AST: Transaminases; ALP: alkaline phosphatase; LDH: lactate dehydrogenase; T.P: Total protein; ALB: Albumin; GLB: Globulin.

In each column means with different letters are significantly different $(\mathrm{P} \leq 0.05)$. 


\section{REFERENCES}

1) Adams RP (1995). In identification of essential oil components by GC-MS. Allured, Carol Stream.

2) Ajith TA, Hema U and Aswathy MS (2007). Zingiber officinale Roscoe prevents acetaminophen-induced acute hepatotoxicity by enhancing hepatic antioxidant status. Food Chem. Toxicol. 45:2267- 2272.

3) Akhani SP, Vishwakarma SL and Goyal RK (2004). Anti-diabetic activity of Zingiber officinale in streptozotocin-induced type I diabetic rats. J. Pharm. Pharmacol. 56:101105.

4) Al-Amin ZM, Thomson M, Al-Qattan KK, Peltonen-Shalaby $R$ and Ali $M$ (2006). Anti-diabetic and hypolipid-emic properties of ginger (Zingiber officinale) in streptozotocin-induced diabetic rats. Br. J. Nutr., 96: 660-666.

5) Alarcon-Aguilara FJ, Roman Ramos R, Perez-Gutierrez S, Aguilar-Contreras A, Cont-reras Weber CC and Flores-Saenz JL (1998). Study of the anti-hyperglycemic effects of plants used as antidiabetics. J. Ethnopharmacol. 61:101-110.

6) Allain CC, Poon LS, Chan CS, Richmond W and Fu PC (1974).Enzymatic determination of total serum cholesterol. Clin. Chem. 20: 470-475.

7) Anon R (1972). Determination of lactate dehydrogenase activity. Z. Klin. Chem. U. Klin. Biochem. 8: 658-860.

8) Arctander S (1969). In Perfume and Flavor Chemicals, Published by the author, Montclair, New Jersey.

9) Atoui AK, Mansouri A, Boskou G and Kefalas $P$ (2005). Tea and herbal infuseions:Their antioxidant activity and phenolic profile. Food Chem. 89: 27-36.

10) Babenko N A and Shakhova EG (2006). Effects of Cham-omilla recutita flavonoids on age-related liver sphingolipid turnover in rats. Exp. Gerontol. 41: 32-39.

11) Babenko NA and Shakhova EG (2008). Effects of flavor-noids on sphingolipid turnover in the toxin-damaged liver and liver cells. Lipids Health Dis. 7: 1-6.

12) Baily NT (1994). Statistical methods in biology, $3^{\text {rd }}$ ed., Cambridge University press, London.

13) Bartel H, Bohmer $M$ and Heierli $C$ (1972). Serum creatinine determination with-out protein precipitation. Clin. Chem. Acta. 37: 193-197.
14) Bergmeyer HU, Bowers GN, Horder $M$ and Moss DW (1976). Provisional recommendations on IFCC methods for the measurement of catalytic concentrations of enzymes. Part2.IFCC method for aspa-rtate amintransferease. Clin. Chim . Acta. 70: 1929.

15) Boelens $M H$ and Boelens $H$ (1997). Chemical and sensory evaluation of three sage oils. Perfumer and Flavorist. 22: 19.40.

16) Britton RS and Bacon BR (1994). Role of free radicals in liver diseases and hepatic fibrosis.Hepatogastroenterology. 41: $343-$ 348.

17) Campanella L, Bonanni A and Tomassetti M (2003). Determination of the antio-xidant capacity of samples of different types of tea, or of beverages based on tea or other herbal products, using a superoxide dismutase biosensor r. J. Pharmaceut. and Biomed. Anal. 32: 725-736.

18) Cemek M, Kağa $S$, Simşek N, Büyükokuroğlu ME and Konuk M (2008). Antih-yperglycemic and antioxidative potential of Matricaria cham-omilla L. in streptozotocin-induced diabetic rats. Nat. Med. (Tokyo). 62: 284-93.

19) Chen HC, Sheu MJ, Lin LY and Wu CM (2007). Chemical Composition of the leaf esse-ntial oil of Psidium guajava $\mathrm{L}$. from Taiwan. J. Essent. Oil Res. 19: 345-347.

20) Chhetri DR, Parajuli $P$ and Subba GC (2005). Anti-diabetic plants used by Sikkim and Darjeeling Himalayan tribes. J. Ethnopharmacol. 99: 199-202.

21) Da-Silva JD, Luz AIR, da Siva MHL, Andrade EHA, Zoghbi MGB and Maia JGS (2003). Essential oils of the leaves and stems of four Psidium spp. Flav. Frag. J. 18: 240-243.

22) Doumas BT and Biggs HG (1972). Determination of serum albumin. In: Standard methods of Clinical Chemistry, vol. 7, Academic Press, New York.

23) Eddokus M, Jouad H, Maghrani $M$, Lembhardi A and Burcelin R (2003). Inhibition of endogenous glu-cose production account for hypoglycemic effect of Sper-gularia purpurea in diabetic mice. Phytomedicine. 10: 594- 599.

24) El-Ghorab A, El-Massry KF and Shibamoto T (2007). Chemical composition of the volatile extract and antioxidant activities of the volatile and non-volatile 
extracts of Egyp-tian corn silk (Zea mays L.). J. Agric. Food Chem. 55: 9124-9127.

25) Finley PR, Schifman RB and williamsm RJ (1978). Cholesterol in high-density lipoprotein: use of $\mathrm{Mg}^{2+} / \mathrm{dex}$-tran sulfate in its enzymic measurement. Clin. Chem. 24: 931-933.

26) Goldberg DM and Spooner RJ (1983). In methods of enzymatic analysis, Bergm-eyen, H. V.(ed.), vol.3, pp.258- 265, Verlog Chemie, Deerfield beach, Fl.

27) Gupta SK, Prakash J and Srivastava S (2002). Validation of traditional claim of Tulsi, Ocimum sanctum Linn. as a medicinal plant. Ind. J. Exp. Biol. 40: 765-773.

28) Gupta AK and Misra $N$ (2006). Hepatoprotective activity of aqueous ethanolic extract of Chamomile capitula in paracetamol intoxicated albino rats. Amer. J. Pharmacol. Toxicol. 1: 17-20.

29) Havsteen BH (2002). The biochemistry and medical significance of the flavonoids. Pharmacol. and Therapeut. 96: 67-202.

30) Herrera-Ruiz M, Román-Ramos R, Zamilpa A, Tort-oriello $\mathbf{J}$ and JiménezFerrer JE (2008). Flavonoids from Tilia americana with anxiolytic activity in plusmaze test. J. Ethnopharmacol. 118: 312-317.

31) Hisaki R, Fujita $H$, Saito $F$ and Kushiro $T$ (2005). Tempol attenuates the develop-pment of hypertensive renal injury in Dahl saltsensitive rats. Amer. J. Hypertens. 18: 707713.

32) International committee for Standardization in Hemat-ology of the European Society of Hematology (ICSHESH) (1965). Recommendations and requirements for hemoglob-inometry in human blood. J. Clin. Path. 18: 335-341.

33) Ito $M$, Murakami $K$ and Yoshino $M$ (2005). Antio-xidant action of eugenol compounds: role of metal ion in the inhibition of lipid peroxidation. Food Chem. Toxicol. 43: 461- 466.

34) Jendrassik $L$ and Grof $P$ (1938). Vereinfact photom-etrische methoden zur bestim-mung des blutbilirubin. Bioc-him. Z. 297: 81-84

35) Kahkonen MP, Hopia AI, Vuorela HJ, Rauha JP, Pihlaja K, Kujala TS and Heinonen M (1999). Antio-xidant activity of plant extracts containing phenolic compounds. J. Agric. Food Chem. 47: 39543962.

36) Katikova OIU, Kostin IAV, Iagudina RI and Tishkin VS (2001). Effect of plant prepa-rations on lipid peroxidation parameters in acute toxic hep-atitis. Vopr. Med. Khim., 47: 593-598.
37) Koracevic D, Koracevic G, Andrejevic V, Koracevic V and Cosic V (2001). Method for the measurement of antio-xidant activity in human fluids. J. Clin. Pathol. 54: 356- 361.

38) Kumazawa $K$ and Masuda $H$ (2002). Identification of potent odorants in different green tea varieties using flavor dilution technique. J. Agric. Food Chem. 50: 56605663.

39) Kovats E (1965). Gas chrom-atographic characterization of organic substances in the retention index system. Ad. Chromat. 1: 229 247.

40) Liang Y, Lu J, Wu S and Wu Y (2003). Estimation of black tea quality by analysis of chem-ical composition and colour differrrence of tea infutions. Food Chem. 80: 283-290.

41) Lin M, Chu QC, Tian $X H$ and Ye JN (2007). Deter-mination of active ingredients in corn silk, leaf, and kernel by capillary electrophoresis with electrochemical detection.Electrophoresis. 10: 51-56.

42) Lohar GW and Wall HD (1974). Glucose6-phosphate dehydrogenase. In method of enzymatic analysis, Bergm-eyer, $\mathrm{H}$. U. Editor, Academic Press, New York.

43) Luczaj W and Skrzydlewska $E$ (2005). Antioxidative prop-erties of black tea. Preventive Med. 40: 910-918.

44) Mac-Sween RNM, Anthony PP and Schever PJ (1994). Pathology of liver, $3^{\text {rd }}$ ed., Longman group limited, Chu-rchill Living Stone Edinburgh, London.

45) Ramadan MM, El-massry KF, AbdelRazak H. Farag and El-Ghorab AH, (2008). Attenuation of hyperglycemia and associated biochemical parameters in STZinduced diabetic rats supplemented by the Egyptian guava (Pisidium guajava L.) leaves volatiles. $3^{\text {rd }}$ Africa Nutritional Epidemiology Conference.

46) Manuele MG, Ferraro $G$ and Anesini $C$ (2008). Effect of Tilia viridis flower extract on the proliferation of a lym-phoma cell line and on normal murine lymphocytes: contrib.ution of monoterpenes, especi-ally limonene. Phytother. Res. 22: 1520-1526.

47) Matsuda $H$, Ninomiya $K$, Shimoda $H$ and Yoshikawa M (2002). Hepatoprotective principles from the flowers of Tilia argentea (linden): struc-ture requirements of tiliroside and mechanisms of action. Bioorg. Med. Chem. 10: 707-12.

48) Nishikimi M, Rao AN and Yagi K (1972). The occurrence of superoxide anion in the reaction of reduced pheuazine methosulfate and molecular oxygen. Biochem. Biophys. Res. Commun. 46: 849-854. 
49) Oberley LW (1988). Free radicals and diabetes. Free Radical Biol. Med. 5: 113-124.

50) Ohkawa H, Ohishi N and Yogi K (1979). Assay for lipid peroxides in animals tissues by thiobarbituric acid reaction. Anal. Biochem. 95: 351-358.

51) Paglia DE and Valentine WN (1967). Studies on the quantitative and qualitative characterization of erythrocyte glutathione peroxidase. J. Lab. Clin. Med. 70: 158-169.

52) Perry NSL, Bollen C, Elaine K, Perry EK and Ballard CC (2003). Salvia for dementia therapy: review of pharma-cological activity and pilot tolerability clinical trial. Pharmacol., Biochem. Behavior. 75: 651-659.

53) Peters TJR (1968). Proposals for standardization of total protein assays. Clin. Chem. 14: 1147-1159.

54) Rau O, Wurglics $M$, Dinge-rmann $T$, Abdel-Tawab $M$ and Schubert-Zsilavecz M (2006). Screening of herbal extracts for activation of the human peroxisome proliferator-activated receptor. Phar-mazie. 11: 952956.

55) Rosalki SB, Foo AY, Burlina A, Prellwitz W, Stieber P, Neumeier D, Klein G, Poppe WA and Bodenmuller $H$ (1993). Multicenter evaluation of Iso-ALP test kit for measurement of bone alkaline phosphatase activity in serum and plasma. Clin Chem. 39: 648-652.

56) Sato $Y$, Hotta N, Sakamoto $N$, Matsuoka $S$, Ohishi N and Yagi K (1979). Lipid peroxide level in plasma of diabetic patients. Biochem. Med. 21: 102-107.

57) Shalev A (1999). Hope for insulin mimetic oral antid-iabetic drugs. Eur. J. End-ocrinol. 141: 561-562.

58) Shobana $S$ and Naidu KA (2000). Antioxidant activity of selected Indian spices.
59) Pros-tagland. Leukot. Essent. Fatty Acids. 62: 107-110.

60) Singh G, Kapoor IPS, Singh P, de Heluani CS, de Lam-pasona MP and Catalan CAN (2008). Chemistry, antioxidant and antimicrobial invest-igations on essential oil and oleoresins of Zingiber office-inale. Food Chem. Tox-icol. 46: 3295-3302.

61) Szasz G (1976). Reaction-rate method for gamma- glutamy-ltransferase activity in serum. Clin. Chem. 22: 2051-2055.

62) Tabacco A, Meiattini F, Moda $E$ and Tarli P (1979). Simplified enzymatic-color-imetric serum urea nitrogen determination. Clin. Chem. 25: 336-337.

63) Tomohiro T, Toshio K, Takeo S, Yuko TB, Shinichi $K$ and Kenjiro $K$ (2007). Hypertension aggravates glom-erular dysfunction with oxid-ative stress in a rat model of diabetic nephropathy. Life Sciences. 80: 1364-1372.

64) Villasenor IM and Lamadrid MRA (2006). Comparative anti- hyperglycemic-potentials of medicinal plants. J. Ethno-pharmacol. 104: 129-131.

65) Visioli F, Borsani L and Galli C (2000). Diet and prevention of coronary heart disease: the potential role of phyt-oche -micals. Cardiovas. Res. 47: 419-425.

66) Wahlefeld AW (1974). In methods of enzymatic analysis, Vol. 5, Bergmeyer, Eds. Academic Press, p. 1831-1835, New York.

67) Wood C, Wagovich MJ and Hollis DM (2001). Herbals, cancer prevention and health. J. Nutr. 131: 3034-3036.

68) Yeum KJ, Taylor A, Tang $G$ and Russell RM (2003). Measurement of carotenoids, retinoids, and tocopherols in human lenses. Invest. Oph-thalmol. Vis. Sci. 36: 27562760 . 



\section{التأثير الوقائي ومضاد للأكسدة لمنقوع خليط من التباتات العطرية ضد الأجهاد التأكسدى التتاتج من الإستربتوزوتوسين ورابع كلوريد الكربون فى الفئران}

خالد فاروق المصري ، أحمد حسن الغراب ، منال محم رمضنان، أحمد محمد جاد قسم كيمياء مكسبات الطعم و الر ائحة ــ المركز القومي للبحوث

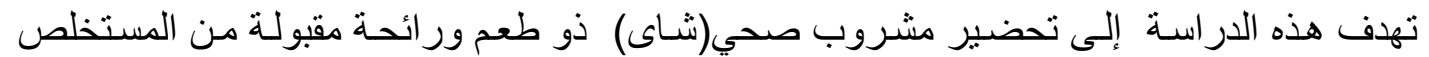

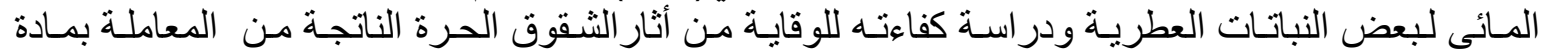

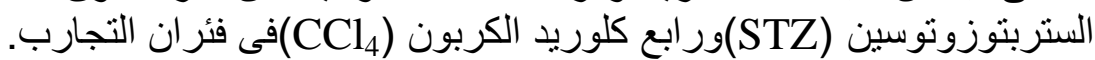

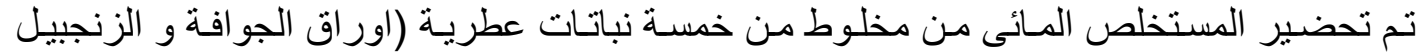

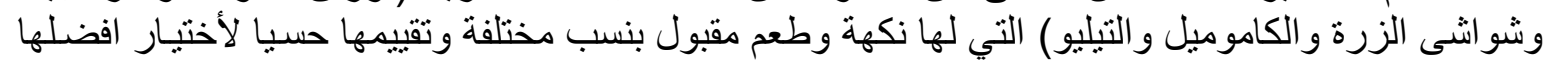

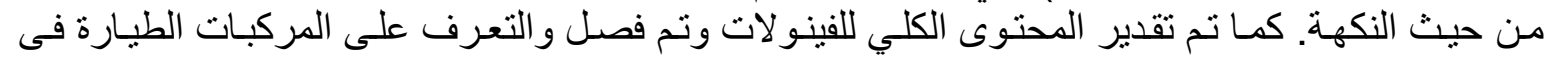

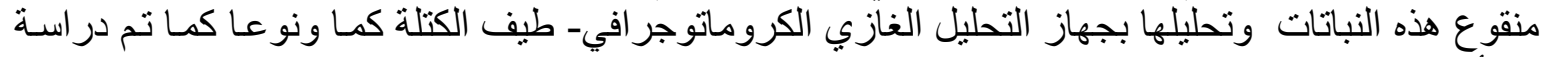

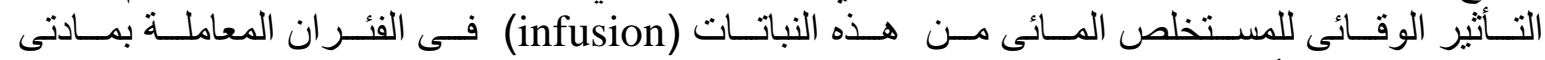

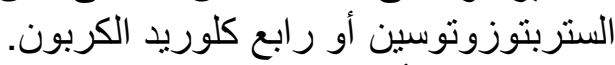
وقد أظهرت التحاليل وجـود مركبـات عطريسة ذات اهميـة كبيرة كمضـادات أكسدة ومسئولة عن النكهة مثل م- 1,8-cineol , cumene, guryunene, $\beta$ - patchoulene, citronellol and zingiberene

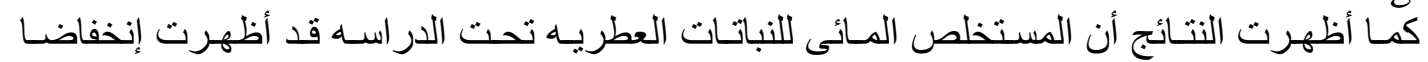

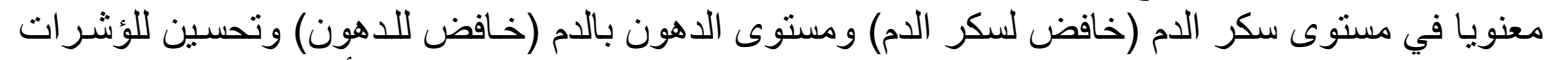

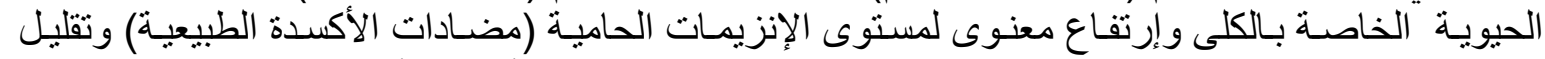

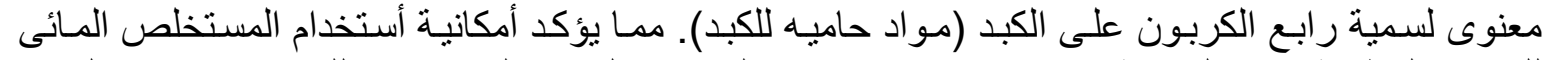

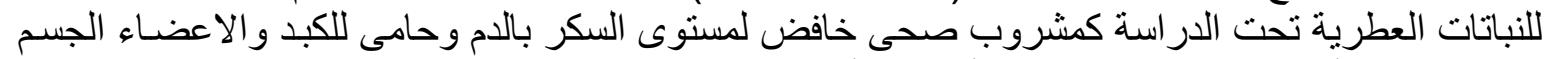
المختلفة من الأثار الضارة الناتجة من الأجهاد التأكسدى. 